\title{
Rhodospirillum sulfurexigens sp. nov., a phototrophic alphaproteobacterium requiring a reduced sulfur source for growth
}

\author{
P. Anil Kumar, ${ }^{1}$ P. Aparna, ${ }^{1}$ T. N. R. Srinivas, ${ }^{1}$ Ch. Sasikala ${ }^{1}$ \\ and Ch. V. Ramana ${ }^{2}$ \\ ${ }^{1}$ Bacterial Discovery Laboratory, Centre for Environment, Institute of Science and Technology, \\ J. N. T. University, Kukatpally, Hyderabad 500 085, India \\ ${ }^{2}$ Department of Plant Sciences, School of Life Sciences, University of Hyderabad, PO Central \\ University, Hyderabad 500 046, India
}

Correspondence

Ch. Sasikala

r449@sify.com

or sasi449@yahoo.ie

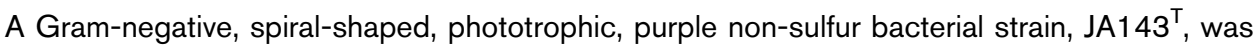
isolated from a freshwater habitat. Strain $\mathrm{JA}_{143^{T}}$ was motile by means of bipolar tufts of flagella. Intracellular photosynthetic membranes are of the lamellar stacked type. Bacteriochlorophyll $a$ and carotenoids of the spirilloxanthin series with rhodovibrin are present as photosynthetic pigments. Thiamine and a reduced sulfur source are required for growth. Phylogenetic analysis on the basis of $16 \mathrm{~S}$ rRNA gene sequences showed that strain $\mathrm{JA} 143^{\top}$ clusters with species of the genus Rhodospirillum, belonging to the class Alphaproteobacteria. The highest sequence similarities of strain $\mathrm{JA}_{143^{\top}}$ were found with the type strains of Rhodospirillum rubrum (95.6\%) and Rhodospirillum photometricum (95.7\%). Based on 16S rRNA gene sequence analysis and morphological and physiological characteristics, strain $\mathrm{JA} 143^{\top}$ was significantly different from the other two recognized species of the genus Rhodospirillum and represents a novel species, for which the name Rhodospirillum sulfurexigens sp. nov. is proposed. The type strain is JA143 ${ }^{\top}$ $\left(=\mathrm{DSM} 19785^{\top}=\right.$ NBRC $\left.104433^{\top}\right)$.
\end{abstract}

The genus Rhodospirillum comprises nine species with validly published names; six of these have been reclassified in other genera (Imhoff et al., 1998), and Rhodospirillum centenum is a synonym of Rhodocista centenaria. The remaining two species, Rhodospirillum rubrum and Rhodospirillum photometricum, can both assimilate sulfate as a source of sulfur (Imhoff, 2005). In this communication, we propose a novel species of the genus Rhodospirillum that requires a reduced sulfur source for growth.

Strain JA143 ${ }^{\mathrm{T}}$ was isolated from a water sample (approx. $\mathrm{pH} 7.2,30{ }^{\circ} \mathrm{C}$ ) which was collected on 18 March 2007 from the freshwater reservoir at Mudasarlova, Visakhapatnam, India $\left(17^{\circ} 45^{\prime} \mathrm{N} 83^{\circ} 17^{\prime} \mathrm{E}\right)$. Original enrichment of the strain was from mineral medium (Biebl \& Pfennig, 1981) [anaerobic, $1 \mathrm{mM} \mathrm{Na} 2 \mathrm{~S} .9 \mathrm{H}_{2} \mathrm{O}$ plus $0.3 \%$ (w/v) pyruvate]. Subsequent culturing, purification and characterization were done in the same medium supplemented with $\mathrm{Na}_{2} \mathrm{~S}_{2} \mathrm{O}_{3} \cdot 5 \mathrm{H}_{2} \mathrm{O}(6 \mathrm{mM})$ in place of $\mathrm{Na}_{2} \mathrm{~S} .9 \mathrm{H}_{2} \mathrm{O}$. Purification and polyphasic taxonomic studies were carried

The GenBank/EMBL/DDBJ accession number for the 16S rRNA gene sequence of strain $\mathrm{JA} 143^{\mathrm{T}}$ is $\mathrm{AM} 710622$.

Electron micrographs of cells of strain $\mathrm{JA} 143^{\top}$ are available as supplementary material with the online version of this paper. out as described previously (Srinivas et al., 2007). 16S rRNA gene sequences were aligned using the CLUSTAL_X program (Thompson et al., 1997) and the alignment was corrected manually. The alignment file was saved with '.phy' extension. The dendrogram was constructed using the PhyML program (Guindon \& Gascuel, 2003) using 100 replicates of nonparametric bootstrap analysis, the GTR model of nucleotide substitution and four substitution rate categories.

Cells of strain JA143 ${ }^{\mathrm{T}}$ are spiral shaped, 1.0-1.3 $\mu \mathrm{m}$ wide; one single turn is 8-9 $\mu \mathrm{m}$ long. Cells also form long chains, more than $30 \mu \mathrm{m}$ long (Fig. 1) and multiply by binary fission. Strain JA143 ${ }^{\mathrm{T}}$ is motile by means of bipolar tufts of flagella (Supplementary Fig S1, available in IJSEM Online). Transmission electron photomicrographs of ultrathin sections of the strain revealed a lamellar stacked type of internal membrane structures (Supplementary Fig. S2). Strain JA143 ${ }^{\mathrm{T}}$ was able to grow photoorganoheterotrophically [anaerobic, light $(2400 \mathrm{~lx})$, with pyruvic acid $(0.3 \%, \mathrm{w} / \mathrm{v})$ as carbon source/electron donor and $\mathrm{Na}_{2} \mathrm{~S}_{2} \mathrm{O}_{3} \cdot 5 \mathrm{H}_{2} \mathrm{O}(2 \mathrm{mM})$ as sulfur source]. Photolithoautotrophy [anaerobic, light (2400 lx), $\mathrm{Na}_{2} \mathrm{~S} .9 \mathrm{H}_{2} \mathrm{O}(2 \mathrm{mM}) / \mathrm{Na}_{2} \mathrm{~S}_{2} \mathrm{O}_{3} \cdot 5 \mathrm{H}_{2} \mathrm{O}(6 \mathrm{mM})$ and $\left.\mathrm{NaHCO}_{3}(0.1 \%, \mathrm{w} / \mathrm{v})\right]$, chemolithoautotrophy [aerobic, dark, $\mathrm{Na}_{2} \mathrm{~S}_{2} \mathrm{O}_{3} \cdot 5 \mathrm{H}_{2} \mathrm{O}(2 \mathrm{mM})$ and $\mathrm{NaHCO}_{3}(0.1 \%$, w/v)], chemoorganoheterotrophy [aerobic, dark, pyruvate 


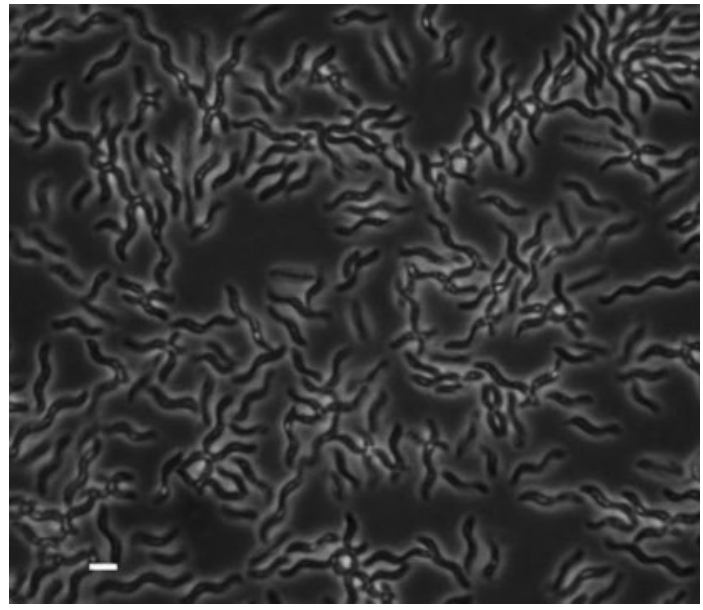

Fig. 1. Phase-contrast micrograph of cells of strain $\mathrm{JA} 143^{\top}$. Bar, $5 \mu \mathrm{m}$.

Table 1. Differentiating characteristics of strain $\mathrm{JA} 143^{\top}$ and species of the genus Rhodospirillum

Data for reference species were taken from Imhoff (2005). +, Substrate utilized or present; -, substrate not utilized or absent; (+), weak growth; \pm , strain-dependent reaction; ND, not determined; NA, no data available. All strains are spiral shaped, divide by binary fission and are motile. Organic substrate utilization was tested during photoheterotrophic growth. Acetate, butyrate, pyruvate, fumarate, malate, succinate and valerate were utilized by all the taxa. Benzoate, citrate, formate and tartrate were not utilized by any of the taxa.

\begin{tabular}{|c|c|c|c|}
\hline Characteristic & $\mathrm{JA} 143^{\mathrm{T}}$ & Rsp. rubrum & Rsp. photometricum \\
\hline Cell width $(\mu \mathrm{m})$ & $1.0-1.3$ & $0.8-1.0$ & $1.1-1.5$ \\
\hline Length and width of a complete spiral turn $(\mu \mathrm{m})$ & $8-9 \times 2.5-3.0$ & $7-10 \times 1.5-2.5$ & $4-7 \times 2.5-4.0$ \\
\hline Colour & Pink & Pink to deep red & $\begin{array}{c}\text { Brown-orange to brown-red/dark } \\
\text { brown }\end{array}$ \\
\hline Main carotenoid(s) & Rhodovibrin & Spirilloxanthin & Rhodopin and lycopene \\
\hline Internal membrane system & Stacks & Vesicles & Stacks \\
\hline Assimilatory sulfate reduction & - & + & + \\
\hline DNA G + C content $(\mathrm{mol} \%)$ & 64.7 & $63.8-65.8$ & $64.8-65.8$ \\
\hline Growth factors & Thiamine & Biotin & Nicotinamide \\
\hline Dark aerobic growth & - & + & - \\
\hline Photolithoautotrophic growth & - & + & - \\
\hline \multicolumn{4}{|l|}{ Use as carbon source/electron donor of: } \\
\hline Arginine & - & + & - \\
\hline Aspartate & - & + & \pm \\
\hline Caproate & + & + & - \\
\hline Caprylate & - & NA & - \\
\hline Ethanol & - & + & + \\
\hline Fructose & $(+)$ & \pm & + \\
\hline Glucose & $(+)$ & - & + \\
\hline Glutamate & $(+)$ & + & - \\
\hline Glycerol & - & - & + \\
\hline Glycolate & - & NA & + \\
\hline Lactate & $(+)$ & + & + \\
\hline Mannitol & - & - & + \\
\hline Methanol & - & \pm & - \\
\hline Pelargonate & $\mathrm{ND}$ & NA & \pm \\
\hline Propionate & - & + & \pm \\
\hline
\end{tabular}




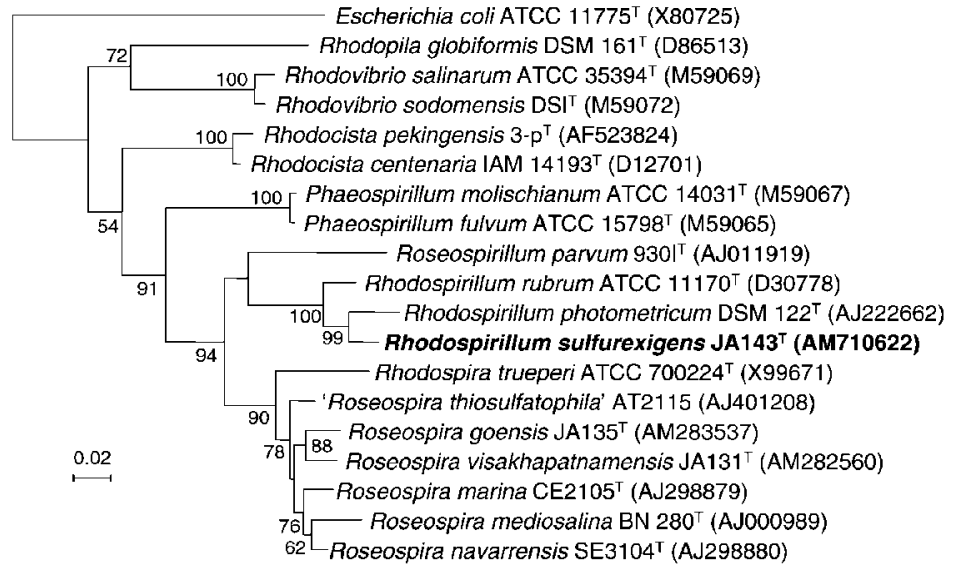

Fig. 2. Dendrogram depicting the phylogenetic relationships of strain $\mathrm{JA} 143^{\top}$ within the family Rhodospirillaceae determined using $16 \mathrm{~S}$ rRNA gene sequence analysis. The dendrogram was constructed using the PhyML method. Numbers at nodes are bootstrap values; values below 50 were removed from the dendrogram. Bar, 2 substitutions per 100 nucleotide positions. to $1.5 \%(\mathrm{w} / \mathrm{v}) \mathrm{NaCl}$. The $\mathrm{pH}$ range for strain $\mathrm{JA} 143^{\mathrm{T}}$ is 6.5-7.5, with an optimum at $\mathrm{pH}$ 7.0. The temperature range is $25-35{ }^{\circ} \mathrm{C}$ and the optimum is $30{ }^{\circ} \mathrm{C}$. Photosynthetically grown cultures are pink. The wholecell absorption spectrum of strain JA143 ${ }^{\mathrm{T}}$ showed absorption maxima at 374, 473, 500, 530, 590, 791 and $848 \mathrm{~nm}$, confirming the presence of bacteriochlorophyll $a$, and the absorption spectrum for pigments extracted with ethanol gave absorption maxima at 454, 482 and $515 \mathrm{~nm}$, indicating the presence of carotenoids of the spirilloxanthin series. Two peaks at 791 and $884 \mathrm{~nm}$ (shoulder peak) were observed.

The DNA base composition of strain JA143 ${ }^{\mathrm{T}}$ was 64.7 mol\% G + C (by HPLC). The phylogenetic relationship of strain $\mathrm{JA} 143^{\mathrm{T}}$ to other purple non-sulfur bacteria was examined on the basis of $16 \mathrm{~S}$ rRNA gene sequences. The data obtained revealed that the new isolate clustered with the type strains of Rhodospirillum species but was distinct from other genera of purple non-sulfur bacteria (Fig. 2). The highest sequence similarities of strain JA143 ${ }^{\mathrm{T}}$ was found with the type strains of Rhodospirillum photometricum (95.72\%) and Rhodospirillum rubrum (95.58\%) (Fig. 2). Apart from 16S rRNA gene sequence dissimilarity, strain $\mathrm{JA} 143^{\mathrm{T}}$ also showed clear phenotypic differences from other Rhodospirillum species (Table 1) that justify the description of the strain JA143 ${ }^{\mathrm{T}}$ as the type strain of a novel species, Rhodospirillum sulfurexigens sp. nov.

\section{Description of Rhodospirillum sulfurexigens sp. nov.}

Rhodospirillum sulfurexigens (sul.fu.re'xi.gens. L. n. sulfur -uris sulfur, L. v. exigo to demand; N.L. part. adj. sulfurexigens sulfur-demanding, referring to the requirement for a reduced sulfur source for growth).

Cells are spiral shaped, $1.0-1.3 \mu \mathrm{m}$ wide; one single turn is 8-9 $\mu \mathrm{m}$ long. Cells also form long chains of more than $30 \mu \mathrm{m}$ long, multiply by binary fission and are motile by means of bipolar tufts of flagella. Internal photosynthetic membranes are lamellar stacks. The colour of phototrophic culture is pink. The in vivo absorption spectrum of intact cells in sucrose exhibits maxima at $374,473,500,530,590$, 791 and $848 \mathrm{~nm}$, indicating the presence of bacteriochlorophyll $a$ and carotenoids of the spirilloxanthin series. Mesophilic $\left(30{ }^{\circ} \mathrm{C}\right)$, with a $\mathrm{pH}$ optimum at 7.0 for growth. Photoorganoheterotrophy with a few organic compounds is the preferred mode of growth. Pyruvate, caproate, crotonate, malate, fumarate and valerate are good carbon sources. Growth also occurs on acetate, butyrate, succinate, glucose, fructose, glutamate and lactate. Photoautotrophic and chemotrophic growth is not possible. There is no assimilatory sulfate reduction. Requires thiosulfate, sulfide, thioglycollate, cysteine or methionine as sulfur sources. Thiamine is required as a growth factor. The DNA base composition of the type strain is $64.7 \mathrm{~mol} \% \mathrm{G}+\mathrm{C}$ (by HPLC).

The type strain, JA143 ${ }^{\mathrm{T}}\left(=\mathrm{DSM} 19785^{\mathrm{T}}=\mathrm{NBRC} 104433^{\mathrm{T}}\right)$, was isolated from a water sample from the freshwater reservoir at Mudasarlova, Visakhapatnum, India.

\section{Acknowledgements}

We thank Dr J. Euzéby for his expert suggestion for the correct species epithet and Latin etymology. Financial assistance received from the Ministry of Earth Sciences, Government of India, is acknowledged. P.A.K. and T.N.R.S. acknowledge the CSIR, Government of India, for the award of SR fellowships. P.A. acknowledges APNL Biotech Programme for the award of a JR fellowship.

\section{References}

Biebl, H. \& Pfennig, N. (1981). Isolation of members of the family Rhodospirillaceae. In The Prokaryotes, pp. 167-273. Edited by M. P. Starr, H. Stolp, H. G. Trüper, A. Balows \& H. G. Schlegel. New York: Springer.

Guindon, S. \& Gascuel, O. (2003). A simple, fast, and accurate algorithm to estimate large phylogenies by maximum likelihood. Syst Biol 52, 696-704.

Imhoff, J. F. (2005). Genus I. Rhodospirillum Molisch 1907, $24^{\mathrm{AL}}$ emend. Imhoff, Petri and Süling 1998, 796. In Bergey's Manual of Systematic Bacteriology, 2nd edn, vol. 2, part C, pp. 1-6. Edited by D. J. Brenner, N. R. Krieg, J. T. Staley \& G. M. Garrity. New York: Springer. 
Imhoff, J. F., Petri, R. \& Süling, J. (1998). Reclassification of species of the spiral-shaped phototrophic purple non-sulfur bacteria of the $\alpha$-Proteobacteria: description of the new genera Phaeospirillum gen. nov., Rhodovibrio gen. nov., Rhodothalassium gen. nov. and Roseospira gen. nov. as well as transfer of Rhodospirillum fulvum to Phaeospirillum fulvum comb. nov., of Rhodospirillum molischianum to Phaeospirillum molischianum comb. nov., of Rhodospirillum salinarum to Rhodovibrio salinarum comb. nov., of Rhodospirillum sodomense to Rhodovibrio sodomensis comb. nov., of Rhodospirillum salexigens to Rhodothalassium salexigens comb. nov. and of
Rhodospirillum mediosalinum to Roseospira mediosalina comb. nov. Int J Syst Bacteriol 48, 793-798.

Srinivas, T. N. R., Anil Kumar, P., Sasikala, Ch. \& Ramana, Ch. V. (2007). Rhodovulum imhoffii sp. nov. Int J Syst Evol Microbiol 57, 228-232.

Thompson, J. D., Higgins, D. G., Gibson, T. J., Plewniak, F., Jeanmougin, F. \& Higgins, D. G. (1997). The CLUSTAL_X windows interface: flexible strategies for multiple sequence alignment aided by quality analysis tools. Nucleic Acids Res 25, 4876-4882. 